ISSN (print) $0867-2008$ / ISSN (online) 239 I-75 12

DOI: http://dx.doi.org/10.12775/OM.2021.014

\author{
Anthony LutTRELL* \\ Emeritus \\ 20 Richmond Place \\ Bath BA1 5PZ \\ United Kingdom \\ margaretluttrell@gmail.com
}

\title{
THE HOSPITALLER BACKGROUND OF THE TEUTONIC ORDER**
}

\section{KEYWORDS}

history; the Middle Ages; military orders; Teutonic Order; Hospitallers; Jerusalem; Acre; Frederick of Swabia

\begin{abstract}
This article examines the foundation in I I 90/ I I 9 I of a German field hospital outside the walls of Acre during its siege by the Christians studied against a background of Hospitaller affairs in Jerusalem before its loss in I 87 . The article relies on contemporary texts rather than the myths which rapidly appeared, while documents issued by the papal chancery suggest misunderstandings of the situation in Syria. The field hospital was the creation of Germans arriving at Acre by sea and overland but its later development inside the walls was, at least partly, conditioned by the long-term mistrust and strife between Romance-speaking and Germanic parties in Jerusalem where the Germans established, at some distance from the main Hospitaller compound, a separate church and hospital dedicated to Santa Maria Alamannorum. In I 43 the pope adjudicated that the Germans were to be subject to the Hospital but were to be administered by Germans speaking German to those for whom they cared. By I I 87 there were Hospitaller brethren and possessions in German lands but Santa Maria Alamannorum seems not to have had its own members or properties there. Those Germans at Acre in I I 90/ I I 9 I would have known about their Jerusalem hospital but would not have sought an institutional link with it because that
\end{abstract}

${ }^{*}$ No ORCID-number.

** This study derives from preparations for a publication on the Hospitaller Priory of "Alamania" made in collaboration with Karl Borchardt, to whom the following is greatly indebted; it scarcely reports the very extensive debate on the origins of the Teutonic Order and it leaves much room for desirable further research on the early German Hospital. First published in: Religiones militares. Contributi alla storia degli Ordini religioso-militari nel medioevo, eds. Anthony Luttrell and Francesco Tommasi, Biblioteca di Militia Sacra 2 (Città del Castello: Selecta, 2008), 27-42. 
would have recognized Hospitaller claims to control them. In I 87 the Hospitaller Master and many brethren were killed and their Jerusalem headquarters was lost; no new Master was elected for some time and control passed to a succession of evidently disoriented senior officers. A new Master Garnier de Nablus reached Acre in June I I 9 I but by then the Hospitallers' rift with the Germans had hardened. and the Teutonic foundation in Acre successfully maintained its independence. How far the Hospitallers' mismanagement of the situation eventually limited or impoverished their own order's future in German lands remains incalculable.

$\mathrm{T}$ The origins of the Teutonic Order in I I 90 or I I 9 I can usefully be considered as an aspect of Hospitaller history; indeed some years ago Marie-Louise Favreau gave important, detailed attention to this Hospitaller background. ${ }^{1}$ It is now accepted that the Teutonic hospital founded outside Acre in I 190/I I 9 I was not institutionally the successor of the German hospice of Sancta Maria Alamannorum in Jerusalem, which had depended on the Order of the Hospital of Saint John and had been abandoned as a result of the Muslim conquest of Jerusalem in I i 87; as Favreau emphazises, there is no sign of any continuity of membership or of archival survivals. What is disputed by Udo Arnold, Klaus Militzer and others is Favreau's assertion that Sancta Maria in Jerusalem held possessions and had members in Germany before i 87 and continued to do so as an independent corporation thereafter, and that subsequently the newly-founded Teutonic Order sought to secure Sancta Maria's purported European endowments. ${ }^{2}$ Given that much of Favreau's discussion of this question depends on silences in the sources and that certain documents involved were forgeries, the matter necessarily remains extremely hypothetical.

The protracted dispute over the Teutonic Order's rights to the former German hospital in Jerusalem came only with the Latin reoccupation of the holy city in I 229 which led to the Teutonic Order and the Hospital both claiming that hospital. ${ }^{3}$ The main narrative source on the origins of the Teutonic Order in I I $90 / 1$ I 91 ,

I Marie-Luise Favreau, Studien zur Frühgeschichte des Deutschen Ordens (Stuttgart: Ernst Klett, I 974); ead., "Alle origini dell'Ordine Teutonico: continuità o nuova fondazione dell'Ospedale Gerosolimitano degli Alemanni?” in Militia Sacra: gli Ordini militari tra Europa e Terrasanta, eds. Enzo Coli et al. (Perugia: San Bevignate, 1994).

2 Most importantly, Udo Arnold, "Jerusalem und Akkon: zur Frage von Kontinuitat oder Neugriindung des Deutschen Ordens I 190," Mitteilungen des Institutes für Österreichische Geschichtsforschung 86 (1978): 4I 8-432; id., "Entstehung und Frühzeit des Deutschen Ordens," in Die geistlichen Ritterorden Europas, ed. Josef Fleckenstein and Manfred Hellmann (Sigmaringen: Thorbecke, 1980), 81-107; and Klaus Militzer, Von Akkon zu Marienburg: Verfassung, Verwaltung und Socialstruktur des Deutschen Ordens I190-1310 (Marburg: N. G. Elwert, I 999), 9-23.

3 Favreau-Lilie, Studien, 89-94; ead.,"Alle origini," 33-34; Helmuth Kluger, Hochmeister Hermann von Salza und Kaiser Friedrich II.: Ein Beitrag zur Frühgeschichte des Deutschen Ordens (Marburg: N. G. Elwert, I987), I 26-I 32. 
the Narratio de Primordiis Ordinis Theutonici, was probably written soon after I 244 and is evidently biased and partly unreliable; the original is lost and the text survives in two mid-fourteenth century versions. The very limited information given briefly in the Continuation de Guillaume de Tyr, probably also completed in the I 240's, is equally of dubious value. Both accounts were written after I 229, yet with necessary and repeated reservations, their use is unavoidable; as narratives their content may have a value which differs from the tendentious claims made in many charters. A number of contemporary documents dating to I I 9 I and I 92 have proved to be confused, unreliable or, in some cases, forged. For the rest, given the extraordinary rapidity with which foundation myths concerning the Teutonic Order developed, most relevant documents later than those which were strictly contemporary with the events of I I 90 and I I 9 I are here ignored.

Very few histories of the military-religious orders consider all the orders as a class. ${ }^{4}$ Their development has traditionally been presented mainly in terms of individual orders, and scholars have often sought a precise year as the "foundation" date for each such order. It has generally been assumed that there was already such a thing as a religious "order" early in the twelfth century, but it may be better to see matters as evolving more gradually and to refrain from imposing later defi-

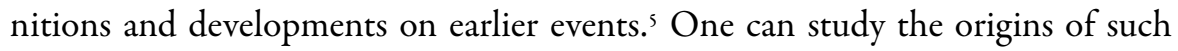
institutions without considering whether they were definable as an "order" with an organized administration, or had a formal approved rule, or received papal recognition or demanded vows of religion from their members.

The first military-religious order, that of the Temple, was founded in I I 20 and approved at the Council of Troyes in I 29 when its primitive Rule was established. The Hospital had originated over fifty years earlier as a pilgrim hospice dependent on the Latin, Benedictine monastery at Jerusalem. In or very soon after the Latin conquest of Jerusalem in 1099 this hospice somehow moved away from the direction of the Benedictines and began to function under the supervision of the newly-installed Augustinian Canons of the Holy Sepulchre. In I I 3 the papacy recognized the Hospital as an independent institution which apparently consisted of religious, since its members were described as fratres and professi by the pope who in that year granted them the right to elect their own superior. ${ }^{6}$ Meanwhile a very small group of Latin armsbearers was somehow attached, proba-

4 Alan Forey, The Military Orders from the Twelfth to the Early Fourteenth Centuries (Basingstoke: MacMillan, 1992), and Alain Demurger, Chevaliers du Christ: les Ordres religieux-militaires au Moyen Age (XI ${ }^{e}-X V I^{e}$ siecle) (Paris: Seuil, 2002), are the best recent exceptions.

5 Cf. Christopher Tyerman, The Invention of the Crusades (Basingstoke: Red Globe Press, I 998 ).

6 Rudolf Hiestand, "Die Anfänge der Johanniter," in Die geistlichen Ritterorden, ed. Josef Fleckenstein and Manfred Hellmann (Sigmaringen: Thorbecke, I 980), 3 I -80; Anthony Luttrell, "The 
bly in a temporary way as milites ad terminum, to the Holy Sepulchre under a vow of obedience to its prior. These proto-Templars apparently resided in the Hospital buildings but in I 20 a number of these "knights" sought to be relieved of their vow to the Holy Sepulchre and moved away to establish the Templar Order. ${ }^{7}$ It was only thereafter, perhaps in the I 130 s, that the Hospital began, in a gradual way, to become militarized.

The Hospitallers and the Templars required men and money which were largely raised by recruitment in the West and through alms-collection and donations of lands and privileges there. Both orders organized these resources into a system of commanderies or preceptories which were, in turn, grouped in provinces or priories. ${ }^{8}$ The Hospital and the Temple were, from their earliest times, recognized in the East as clearly separate, individual institutions which men could join and to which grants could be made, but that was not the case in the West where initially there was considerable confusion in the public mind. Before 1099 the Jerusalem hospice had no endowments and was financed by the Amalfitan merchants who had founded it. On the other hand, in the West some donations were made to the Holy Sepulchre even before the first crusade. After 1099 monies were initially collected jointly on behalf of both Holy Sepulchre and Hospital. People in Europe frequently failed to distinguish clearly between the two, and the clerical canons, the hospitable carers and the armsbearing group were sometimes regarded as the liturgical, charitable and military wings of a single broad Holy Sepulchre establishment in Jerusalem. The Hospital and Temple had a greater need for Western support than the canons, who were slow to organize their resources in Europe, and in some cases at least the Hospitallers somehow took over various foundations which had not originally been explicitly intended for them; some of these were initially dedicated to the Holy Sepulchre and in certain cases the Hospitallers subsequently changed that dedication.?

Earliest Hospitallers," in Montjoie: Studies in Crusade History in Honour of Hans Eberhard Mayer, eds. Benjamin Kedar et al. (Aldershot: Variorum, 1997), 37-54.

7 Anthony Luttrell, "The Earliest Templars," in Autour de la première Croisade, ed. Michel Balard (Paris: Publications de la Sorbonne, 1996), 193-202; Id., "Templari e Ospitalieri: alcuni confronti," in I Templari la guerra e la santità, eds. Simonetta Cerrini, Fulvio Bramato, and Franco Cardini (Rimini: Iniziative Editoriali Il Cerchio, 2000), I 33 - I 52.

8 Jonathan Riley-Smith, "The Origins of the Commandery in the Temple and the Hospital," in La Commanderie: Institution des Ordres Militaires dans l'Occident Médiéval, ed. Anthony Luttrell and León Pressouyre (Paris: Comité des travaux historiques et scientifiques, 2002), 9- 8 (and other contributions); Anthony Luttrell, "Los Orígines de la Encomienda templaria” [forthcoming].

9 Hiestand, "Die Anfänge," 47-53; Luttrell, “The Earliest Templars," 43-52; Id., "Gli Ospedalieri nel Mezzogiorno," in Il Mezzogiorno normanno-svevo e le Crociate, ed. Giosuè Musca (Bari: Edizioni Dedalo, 2002), 289-300. 
By about I I 40 there a considerable body of Hospitallers, whose order did not yet include a class of milites or "knights", in the Jerusalem kingdom, while other brethren served in commanderies or domus in many Western countries, including the Hispanic kingdoms. For the Germans, however, matters evolved differently in ways about which information is extremely inadequate. For Jerusalem itself, the non-written evidence consists exclusively of the considerable remains of the church of Sancta Maria Alamannorum and its adjacent buildings which were situated some way from the Hospitallers' main hospital complex which was next to the Holy Sepulchre. The recent excavations have not been published in detail, but it was a Romanesque church with a crypt and an upper floor, and abutting it on either side were various rooms, those to the north being built around a large courtyard. There could have been living quarters, dormitories and so on for resident brethren, and quite possibly for sisters, with spaces for pilgrims, the poor and the sick. ${ }^{10}$

The founders of the German hospital are unknown. Probably between I 229 and 1240 Jacques de Vitry, Bishop of Acre, wrote that a German couple had, with the patriarch's consent and at a date not specified, founded a hospital in Jerusalem which had an oratorium dedicated to Saint Mary; and that many Germans, including knights and nobles, gave donations to it or served the sick there in great poverty, taking a vow of poverty and a habit. ${ }^{11}$ In about i 165 the pilgrim Johannes of Würzburg spoke of a domus Alemannorum with a hospital and a church of Saint Mary; he said that church was fit de novo, which left it unclear whether he meant that there was an earlier oratorium being replaced by a new church built just before the mid-i I 6 os or simply a new church. ${ }^{12}$ Sophia Countess of Holland was buried there in 1 I $76 .{ }^{13}$ Late in the fourteenth century Jean of Ypres claimed that the wife of the German founder had added an adjacent hospital for mulieres Alamanne or

10 Arrangements revised in Denys Pringle, "The Churches of the Crusader Kingdom of Jerusalem," vol. 3 [forthcoming], giving details, photographs and plans, and suggesting a possible date in the I I 40s; Denys Pringle most kindly communicated his text before its publication. Jaroslav Folda, The Art of the Crusaders in the Holy Land: 1098-1187 (Cambridge: Cambridge University Press, I 995), 505, 586, attributes the church stylistically as "likely" built in the I I 205.

${ }^{11}$ Jacques de Vitry, "Historia Orientalis," in Gesta Dei per Francos, vol. 2, ed. Jacques Bongars (Hannover: Typis Wechelianis, apud heredes I. Aubrii, I 6 I I ), I 085.

12 Peregrinationes Tres: Saewulf, John of Wiirzburg, Theodoricus, ed. Robert B. C. Huygens (Turnhout: Brepols, I 994), I 33 ; Favreau-Lilie, "Alle origini," 3 I, speaks of a new church replacing the oratorium.

13 “Annales Egmundani," in Monumenta Germaniae Historica: Scriptores, vol. 16, ed. Georg H. Pertz (Hannover: Impensis Bibliopolii Aulici Hahniani, I 859), 468. 
German women; ${ }^{14}$ while there probably was space for a separate women's ward among the various buildings, Jean's remark may have been a late invention.

The major contemporary texts are two papal letters of I I 43 both of which, significantly, remained in the Hospitallers' central archive, parts of which somehow survived the loss of Jerusalem in I i 87; the letter addressed to the German brethren survived in the original. The two letters rejected the Germans' claims to be independent, presumably because it was a general Hospitaller policy to absorb marginal groups which were not under their order's direct control and which would compete with it for members and gifts. In a formal text witnessed by numerous cardinals, the pope confirmed to the Master and brethren of the Hospital in Jerusalem that the Master should "thenceforth" control the prior and servientes of the Germans there but that he should appoint only those de gente Theutonicorum who could speak in their own language to the poor whom they were serving; the privilege evidently referred to Sancta Maria Alamannorum though it did not explicitly mention it. ${ }^{15}$ The creation of a shelter in Jerusalem for Westerners who did not understand a Romance tongue was not unique. In i I 35 , for example, the Holy Sepulchre sold two adjacent houses to a Hungarian woman for use as a hospice for Hungarians; she was to receive from the Holy Sepulchre the upkeep of a canon and a servant, which suggested an interest on the part of the Holy Sepulchre in the maintenance of hospices; ${ }^{16}$ in I $_{1} 67$ she sold the house to the Hospital. ${ }^{17}$ Jerusalem's German community was more considerable and there was a Rue des Alamans. ${ }^{18}$ Sancta Maria Alamannorum may originally have operated as an independent community able to elect its own ruler, since in I 43 it had a prior and

14 Johannes Longus de Ipra, "Chronica Monasterii Sancti Bertini," ed. Oswald Holder-Egger, in Monumenta Germaniae Historica: Scriptores, vol. 25, ed. Georg Heinrich Pertz (Hannover: Impensis Bibliopolii Aulici Hahniani, i 880), 796.

is Cartulaire général de l'Ordre des Hospitaliers de S. Jean de Jérusalem (IIO0-I3IO), vol. I (IIOo-I200), ed. Joseph Delaville Le Roulx (Paris: Ernest Leroux, I 894), nos. I54-I55; reed. in Rudolf Hiestand, Papsturkunden für Kirchen im Heiligen Lande (Göttingen: Vandehoeck \& Rupprecht, I985), I69-172.

16 Le Cartulaire du Chapitre du Saint-Sépulchre de Jérusalem, ed. Geneviève Bresc-Bautier (Paris: Paul Geuthner, I 984), no. I I ; the Master of the Hospital was a witness.

17 Cartulaire général, I, ed. Delaville Le Roulx, no. 372 (at 4, 248-249).

18 Possibly there was another German church: Klaus Bieberstein and Sabine Bieberstein, "St. Thomas Alemannorum oder St. Peter ad Vincula? Zur historischen Identifizierung einen wiederentdeckten Kreuzfahrerkirche in der Altstadt Jerusalems," Zeitschrift des Deutschen Palästina-Vereins 104 (1 988): I 52-16 I. The ecclesia Sancti Thome Alemannorum would be datable only to before i 1 87: Le Cartulaire du Chapitre, ed. Bresc-Bautier, no. 169. Discussion in Favreau-Lilie, Studien, I 2- I 7; Kluger, Hochmeister, I 32-1 34. Saint Thomas seems to have been near the royal palace at some distance from the German hospice in the rue des Alemans. Denys Pringle suspects that Alamannorum may be an error for Armenorum. 
servientes. If there were any professed German Hospitaller milites in Jerusalem they would perhaps have been stationed in the Hospital's main conventual quarters.

The first of the two papal letters of I I 43 indicated that the Germans had a separate hospital in Jerusalem, that they wished to be independent of the main branch of the Hospital, that they did not understand the Romance speech used by most other members of the order, and that they did not wish to find themselves in a hospice or hospital with whose carers they could not speak. The other letter of I 43 was addressed to the fratres Hospitalis Jerosolimitani per Alemaniam constitu$t i$, that is to brethren of the Jerusalem Hospital in Germany, who were said to be involved in dissensions and scandals «both in the Kingdom of Jerusalem and in other parts of the world». The quarrels concerned the German hospital in Jerusalem and the letter repeated that the Master and brethren of the main hospital, the major Hospitalis, were in all ways to control those Germans at Sancta Maria who were caring there for sick pilgrims and speaking their language; this second letter did not mention the poor. The Hospital had evidently claimed that there were German Hospitallers both in Jerusalem and, presumably, Germany who were in dispute with the main body of the order which wanted control over Sancta Maria Alamannorum.

The somewhat chauvinistic Johannes of Würzburg reported in about I I 65 that German visitors to Jerusalem made donations to Sancta Maria, though he did not say that these gifts included properties in Germany; reflecting his countrymen's anti-French attitudes, he remarked of the German house: «few if any men of other tongues bestow anything of value on it $\gg .{ }^{19}$ The papal letters of I I 43 might have been ill-informed or have been purposely inaccurate. In Jerusalem at least, the German hospital seems to have received gifts in its own right and there was a not inconsiderable number of German crusaders and pilgrims in Jerusalem who might have needed their own hospital, ${ }^{20}$ but it is entirely uncertain who would have been the brethren said to be constituti in Germany or wherever they may have been established «in other parts of the world».

In about I I 23/ I I 24 the Master of the Jerusalem Hospital sent collectors to the West and probably some of them went to Germany, since the only two surviving copies of the letters the Master sent with them both survived in Austria. ${ }^{21}$ Late in I 46 or early in I 47 Bernard of Clairvaux, while visiting Germany to preach the new crusade to Syria, addressed an encyclical to numerous recipients.

\footnotetext{
19 Peregrinationes, ed. Huygens, 133 ; cf. Folda, The Art, 405.

20 Rudolf Hiestand, "Kingship and Crusade in Twelfth-Century Germany," in England and Germany in the High Middle Ages, eds. Alfred Haverkamp and Hanna Vollrath (London: Oxford University Press, 1996), 235-266.

${ }^{21}$ At Vienna and Zwettel: Cartulaire général, I, ed. Delaville Le Roulx, no. 47.
} 
One example, surviving in a single copy at Jena, exhorted an anonymous Ierosolymitanorum frater Hospitalis to join the coming crusade. The letter implied that there were Hospitallers in Germany who might have been expected to travel to fight in Syria. In the mid-thirteenth-century manuscript, the letter was headed, in the same hand as the text of the letter itself: Ad fratres Hospitalis Sce. Marie de Expeditione Ierosolimitana. ${ }^{22}$ Possibly, however, this heading, with the reference to fratres in the plural and to Sca. Maria, was introduced by the thirteenth-century copyist, in which case it was not evidence for a brother or brethren of Sancta Maria Alamannorum in Germany in I I 46/ I I $47 .{ }^{23}$ It could be that Sancta Maria in Jerusalem itself did receive property in Germany ${ }^{24}$ and it might be that the main branch of the order had no administrative machinery there until shortly before I I 87. These remain hypotheses; the pope had in I I 43 mentioned Hospitallers who were apparently in Germany as well as possessions claimed by Sancta Maria somewhere outside Jerusalem, conceivably either elsewhere in Syria or in Europe outside Germany, yet no trace of such brethren or possessions survives. Johannes of Würzburg and Jacques de Vitry indicated that Sancta Maria was supported by alms and gifts given in Jerusalem itself.

It may well have been that there were still confusions in Germany, much as there were elsewhere; that there were German supporters of the main Jerusalem Hospital who were never completely absorbed into the main order or who were perhaps devoted mainly to the Sancta Maria hospital; or that informal groups in Germany were founding hospices, perhaps with the support of local communities, which both the main Hospital and Sancta Maria later attempted to control. Whether or not they were professed religious, such Germans could have been part of an institution which had unidentified properties or residences and they could have sent money to Jerusalem; the papal injunction to obedience of I I 43 suggests that they would also have resented interference from the largely French-dominated main Hospital. A possible, but extremely early, case of such detached support

22 Jean Leclercq, "L'Encyclique de Saint Bernard en faveur de la Croisade," Revue Bénédictine $7 \mathrm{I}$ (1971): 290-291; Sancti Bernardi Opera, vol. 8, eds. Jean Leclercq and Henri Rochais (Rome: Editiones Cistercienses, 1977), no. 363. Cf. Bernhard Tönnies, Die Handschriften der Thüringer Universitäts- und Landesbibliothek Jena, vol. I, Die mittelalterlichen lateinischen Handschriften der Electoralis-Gruppe (Wiesbaden: Otto Harrassowitz, 2002), 68-70 (information kindly supplied by Joachim Ott). Jonathan Riley-Smith, The Knights of St. John in Jerusalem and Cyprus: c. 1050-1310 (London: MacMillan, I967), 55, 57, 58 n. 7, remarks that "it is it clear that the letter was addressed to someone in the Order of St. John" and that it may indicate that the Hospital was using mercenary troops.

23 Favreau-Lilie, "Alle origini," 30, 38-39, regards Sancta Maria as initially independent and the existence of German brethren of Sancta Maria in Germany as certain.

24 As claimed ibid., 34. 
could have been that of the seven men mentioned as Jerosolimitani at Utrecht in I 122 when they were given land that was later Hospitaller property and was used for a hospital. Johanna Maria van Winter sees them as perhaps the earliest Hospitallers north of the Alps but their status was very probably much more informal, though they might have been to Jerusalem. ${ }^{25}$

The Hospital's German lands were distinguished from others, in Austria, Hungary, Bohemia, Poland, Scandinavia and elsewhere, which later belonged to the German province of the Hospital but which were outside Germany and mainly outside the order's Priory of Alamania; these other lands were mostly ruled by kings or dukes and not all were German-speaking. In fact, even in the whole of what became the much more extended region or province of Alamania, no identifiable member, house or donation is datable anywhere before the imprecise papal texts of I I 43. An important donation at Mailberg was made by Kdolt von Harras on the «altar of the Holy Baptist John» in Jerusalem, apparently in the I I 40 S and very possibly during the second crusade in I $148 .{ }^{26}$ Mailberg was in Austria and within what eventually became the Priory of Bohemia. In Germany proper, that is excluding Austria, Bohemia and Poland, the earliest documented Hospitaller possession was a church of Saint Mary and Saint John at Duisburg consecrated at the request of the Hospitallers of Jerusalem in I I 52/ i I 54; between I I 67 and I I 89 it acquired a nearby hospital dedicated, significantly, to the Holy Sepulchre. ${ }^{27}$ The German membership of the Hospital had no known local organization until shortly before I I 87, when Arlabaudus Prior of Alamania held his annual prioral chapter at Nidda in Hessen; Arlabaudus was in Syria and was still prior in I I $88 .{ }^{28}$ Since the chapter was a yearly one, its organization was not a novelty in October i i 87.

It was often the practice in twelfth-century Germany not to record donations in written charters, while there might have been German Hospitallers who had

25 Oorkondenboek van het Sticht Utrecht tot I30I, vol. I, eds. Samuel Muller, Arie Cornelis Bouman, Klaas Heeringa, and Frans Ketner (Utrecht: Oosthoek, I 920), nos. 308-309; cf. Johanna Maria van Winter, "Les Seigneurs de Sainte-Catharine à Utrecht les premiers Hospitaliers au nord des Alpes," in Autour de la première Croisade, 239-246; ead., Sources concerning the Hospitallers of St. John in the Netherlands: 14 th-18th Centuries (Leiden: Brill, 1998 ), I $3-15$.

26 Cartulaire général, I, ed. Delaville Le Roulx, nos. 245-246, redated in Maximilian Weltin, "Die Anfänge der Johanniterkom- menden Mailberg und Stroheim," Mitteilungen des Oberösterreichischen Landesarchivs I 8 (1996): I 89-193; Alain Beltjens, "Comment l'Hôpital de Jérusalem, une Institution religieuse et hospitalière d'Origine bourgeoise, a-t-il pu se transformer en un Ordre militaire et accessoirement hospitalier?," Studi Melitensi 10 (2002): 32, interprets the text as showing that the Hospital was receiving milites as early as circa I 28.

27 Cartulaire général, I, ed. Delaville Le Roulx, nos. 204, 875 (with erroneous summary); Urkundenbuch der Stadt Duisburg, vol. I, eds. Joseph Milz et al. (Duisburg: Droste, I 989), nos. I 2, I 8.

28 Cartulaire général, I, ed. Delaville Le Roulx, nos. 825, 860. 
no houses or residences but who sent money and valuables to Syria which derived from alms rather than from property. ${ }^{29}$ Favreau suggests that the Hospitallers proper had little property in Germany precisely because donors preferred to make gifts to Sancta Maria and it may be that Sancta Maria lost any documents it may have held in I I 87; there is no evidence for her claim that the Hospital had renounced «many donations» in favour of Sancta Maria. ${ }^{30}$ Favreau constantly refers to the loss of the supposed archive of Sancta Maria, but charters documenting Western possessions were normally kept in Western priories or commanderies rather than in Jerusalem, and the problem remains that nothing whatsoever is known of any particular gift of property in Germany held by Sancta Maria. ${ }^{31}$ It was equally the case that there were very few Templar houses in Germany and none before I I $43 .{ }^{32}$ A few donations apart, the main Hospital had, according to Favreau, no need for possessions or for an organized presence in Germany before i 87 since gifts were nevertheless reaching Jerusalem for Sancta Maria. Favreau's various arguments remain largely hypothetical, and there may have been other reasons for the scarcity of German endowments for the Hospital, such as the relatively limited German participation in the crusades to Syria, as also the numerous divisions and quarrels which afflicted twelfth-century Germany.

Those written gifts to the Hospital known to have been made in Germany before I I 87, beginning with that at Duisburg in I I 54/ I I 56, were never addressed to Sancta Maria Alamannorum. Konrad III had been in Syria twice, in I I 24/ I 25 and I I 48, and Frederick I was there in I I 47/ I 4 48. In I 56 and I 58 Frederick I, who mentioned the charitable activity he must himself have witnessed in the main Jerusalem hospital, confirmed the order's possessions throughout the Empire; this confirmation was renewed in I I $85 .{ }^{33}$ The Hospital received a donation at Werben

29 Cf. Karl Borchardt, "Spendenaufrufe der Johanniter aus dem I 3. Jahrhundert," Zeitschrift für bayerische Landesgeschichte 56 (1993): I - 6 I ; id., "Two Forged Thirteenth-Century Alms-Raising Letters used by the Hospitallers in Franconia," in The Military Orders, vol. I, Fighting for the Faith and Caring for the Sick, eds. Malcolm Barber and Helen Nicholson (Aldershot: Ashgate, 1 994), 52-56; id., "Military Orders in East Central Europe," in Autour de la première Croisade, ed. Michel Balard (Paris: Publications de la Sorbonne, 1996), 247-254.

30 Favreau, "Alle origini," 3 I, $38-39$.

31 Investigations by the author and Karl Borchardt confirm the point, made in Arnold, "Entstehung," 91-92, and Militzer, Von Akkon, I 3, that no German possessions of Sancta Maria are known.

32 Karl Borchardt, "The Templars in Central Europe," in The Crusades and the Military Orders: Expanding the Frontiers of Medieval Latin Christianity, eds. Zsolt Hunyadi and Jozsef Laszlovszky (Budapest: Central European University Press, 200 I), 234, 24 I n. 7.

33 Cartulaire général, I, ed. Delaville Le Roulx, nos. 246, 270, 764, discussed in Weltin, "Die Anfänge," I 89-1 92 nos. 246, 270, are apparently partial forgeries. Konrad's first journey is debatable but probable: e.g. Jonathan Phillips, "Papacy, Empire and the Second Crusade," in The 
on the Elbe in I I 60 ; a foundation at Burg on the Wupper was made between I 67 and I I 89, perhaps in I I 87; and a gift was made at Nidda in I I 87. ${ }^{34}$ In I I 72 Henry the Lion, Duke of Saxony and Bavaria, reached Jerusalem where he made gifts of money to the Hospitallers and Templars to support fighting men there. ${ }^{35}$ The schism in the papacy from I 59 to I 177 impeded donations in Germany, but between I I 80 and I 87 there were a number of foundations within Alamania, one at Heimbach for example and others in Switzerland. ${ }^{36}$ When Friedrich, advocatus curie of Regensburg, died in Jerusalem in I 48 he was buried in the Templars' cemetery; in that year Konrad III stayed in the Templars' palace. ${ }^{37}$ In I I 80 Kuno of Buchsee, who went three times to Jerusalem where he stayed not in Sancta Maria but in the main hospital, made a donation at Buchsee in Switzerland. ${ }^{38}$

In I I 8 I / I 82 a Hospitaller ordinance laid down the contributions to be sent to Syria from the West, but Germany was not among those regions which were mentioned. ${ }^{39}$ On his way to Syria in I I 80 the Swiss noble Count Rudolf von Pfullendorf deposited monies at Venice; once in Jerusalem he made a gift, or possibly a repayment, to the Hospital, instructing that the money be handed to the Hospitaller Prior of Venice. The Master sent three Hospitallers as representatives to Venice where the money was paid over. Rudolf died in Jerusalem; whether he was buried in the main hospital, at Sancta Maria Alamannorum or elsewhere is not known, but there was no hint that Sancta Maria Alamannorum was involved in his gift or loan, or that it had any representative in Venice. ${ }^{40}$ In I 163 a Petrus Alam-

Second Crusade: Scope and Consequences, eds. Jonathan Phillips and Martin Hoch (Manchester: Manchester University Press, 200 I ), I 7; Graham Loud, "Some Reflections on the Failure of the Second Crusade," Crusades 4 (2005): 4.

34 Cartulaire général, I, ed. Delaville Le Roulx, nos. 289, 825; Anton Jux, Der Johanniterkommende Herrenstrunden nebst Pfarrgeschichte (Bergisch Gladbach: Kulturamt Bergisch-Gladbach, 1956), 22.

35 Arnold of Lübeck, "Chronica Slavorum," in Monumenta Germaniae Historica: Scriptores, vol, 2 I, ed. Georg Heinrich Pertz (Hannover: Impensis Bibliopolii Aulici Hahniani, I 869), I 2 I.

36 These details are not complete even for Germany proper: cf. Favreau-Lilie, Studien, 26-27, 30-33; Walter Gerd Rödel, Das Grosspriorat Deutschland des Johanniter-Ordens im Übergang vom Mittelalter zur Reformation anhand der Generalvisitationsberichte von I494/95 und I 540/4I (Cologne: Wienand, 1972, 2nd edition); Der Johanniter-Orden / der Malteser-Orden: der ritterliche Orden des hl. Johannes vom Spital zu Jerusalem - seine Aufgaben, seine Geschichte, ed. Adam Wienand (Cologne: Wienand, I 988, 3 rd edition).

37 Otto Frisingensis, "Gesta Friderici I. Imperatoris," in Scriptores Rerum Germanicarum in usum Scholarum, ed. Georg Waitz (Hannover: Impensis Bibliopolii Hahniani, I 9 I 2), 89.

38 Cartulaire général, I, ed. Delaville Le Roulx, no. 577.

39 Ibid., no. 627.

40 Marie-Louise Favreau-Lilie, "Zur Pilgerfahrt des Grafen Rudolf von Pfullendorf: ein unbeachteter Originalbrief aus den Jahr i I 80," Zeitschrift für die Geschichte des Oberrheins I 23 no. 84 (1975): $31-46$. 
manus, probably a Frenchman named Aleman but conceivably a German, was the Hospitaller Prior of Constantinople and was due to return to Syria..$^{41}$ In Syria itself a frater Hermanus, who was Castellan of Krak in I 85 and bajalus of Bethany in I I 86 , may have been German. ${ }^{42}$

The immediate general background to the origins of the Teutonic Order was one of multiple crises and of rivalries among the leaders of the Latin kingdom. The Master of the Hospital, Roger de Moulins, was killed in battle on I May I I 87 and the Grand Commander Borrel took command. Many brethren died in the great disaster at Hattin on 4 July, and Jerusalem, with the order's two hospitals, fell on 2 October. Perhaps for lack of electors or of an immediately acceptable candidate, no new Master was elected after the death of Roger de Moulins. The survivors seem, but not until mid-i i 88, to have chosen Ermengol de Aspa, apparently a Catalan, as an interim Master or provisor. In October i i 87 he had been present in Tyre as Prior of Saint-Gilles in Provence, together with Arlabaudus Prior of Alamania and other Western priors. However, by late i 190 Ermengol was back in Spain and no longer acting as interim Master. The next Master Garnier of Nablus, apparently an Eastern Latin who was Prior of England at the time of his election, reached Syria from the West in June I I 9 I in the company of Richard of England, whose confidence he enjoyed. The Hospitallers played an active and important part in the kingdom after Jerusalem fell in October I I 87, but the Latins were deeply divided among themselves; the Hospitallers participated in the defence of Tyre but then withdrew their support from the Latin leader Conrad of Montferrat. There may initially have been pressures from Western crusaders for a Westerner as Master, while others perhaps opposed Westerners who had no Levantine experience. ${ }^{43}$ The family of Milly, Lords of Nablus, were leading barons in

${ }_{41}$ Anthony Luttrell, "The Hospitallers in Twelfth-Century Constantinople," in The Experience of Crusading, vol. I, Western Approaches, eds. Marcus Graham Bull and Norman Housley (Cambridge: Cambridge University Press, 2003), 225.

42 Cartulaire général, I, ed. Delaville Le Roulx, nos. 754, 783.

43 Joseph Delaville le Roulx, Les Hospitaliers en Terre Sainte et à Chypre: 1100-I31o (Paris: Ernest Leroux, 1904), 97-106, 408 n. 2, 426, suggesting that Garnier probably heard of his election between 14 January and 25 March I 90 , though he may have been elected earlier: see also Riley-Smith, The Knights, 106-1 16; Judith Bronstein, The Hospitallers in the Holy Land: Financing the Latin East, II 87-I274 (Woodbridge: Boydell Press, 2005), I I-I 2; Anthony Luttrell, "Ermengol de Aspa Provisor of the Hospital: I i 88," Crusades 4 (2005): I 5 - I 9 . Confusion among the Hospitallers in I 187-1 I 9 I requires further investigation. Jonathan Riley-Smith, "Guy of Lusignan, the Hospitallers and the Gates of Acre," in Dei Gesta per Francos: Crusade Studies in Honour of Jean Richard, eds. Michel Balard [et al.] (Aldershot: Ashgate, 2001), I I 3-- I I 5 , discusses this confusion in the light of Cartulaire général, I, ed. Delaville Le Roulx, no. 972 of 3 I January I 192; note that this edition may have been taken over directly from the Paoli edition of 1733 of the original in Malta. Following the death of Gérard de Ridefort in Oc- 
the Kingdom of Jerusalem and Philip of Nablus was Master of the Temple from I 169 to 1 I 7 I ; ${ }^{44}$ on the other hand a Catalan, Arnau de Torroja, ruled the Temple from I I $80 /$ I I 8 I to I i 84 . The problem of the Mastership of the Hospital was not a new one. The protracted crisis and schism within the Hospitaller order which involved the replacement of Gilibert d'Assailly in I I 70/ I 172 had raised many difficulties; it was claimed that Gilibert had «received» his office from the pope ${ }^{45}$ but his successor was to be chosen by an electoral college of thirteen brethren. ${ }^{46}$ Roger de Moulins himself had been a leading figure in crusading politics, yet his shifting attitudes and his part in the disaster of May I I 87, in which he was killed, had certainly been controversial. ${ }^{4}$

It was reported that after the fall of Jerusalem Saladin allowed ten Hospitallers to remain there to tend the sick in the hospital. ${ }^{8}$ Favreau argues that some members of Sancta Maria survived in i i 87; that «there can be no doubt about the fact that at least many of them» returned to Germany; and that a very brief papal privilege of Clement III of 6 February I I 9 I, which survived in the archives of the Teutonic Order and granted, at the request of unnamed petitioners, a simple protection to the «German brethren of the church of Sancta Maria in Jerusalem», - fratres Theotonici ecclesie Sancte Marie Ierosolimitane - and to their church and their present and future goods, was addressed to the survivors of Sancta Maria Alamannorum. ${ }^{49}$ Hypothetical German survivors could have escaped from Jerusalem and, amid the general confusion, have broken away from the Hospital, and they

tober I I 89, the Templars also left their Mastership vacant, command passing to two successive Grand Commanders; Robert de Sablé, a layman closely connected to Richard I of England, was elected Master, probably at Acre only in June i 19 I: Marie Luise Bulst-Thiele, Sacrae Domus Militiae Templi Hierosolymitani Magistri: Untersuchungen zur Geschichte des Templerordens II I 8/9-I3I4 (Göttingen: Vandenhoeck \& Ruprecht, I 974), I I 7-I I 8, I 24-I 25, I 34, I 45.

44 Malcolm Barber, "The Career of Philip of Nablus in the Kingdom of Jerusalem," in The Experience of Crusading, vol. 2, Defining the Crusader Kingdom, eds. Peter Edbury and Jonathan Phillips (Cambridge: Cambridge University Press, 2003), 60-75.

45 [...] a quo ministerium susceperat: text in Papsturkunden für Templer und Johanniter: Neue Folge, ed. Rudolf Hiestand (Göttingen: Vandenhoeck \& Ruprecht, 1984), 222-230, with revised dating.

46 Ibid., 222-227.

47 Cf. Riley-Smith, The Knights, 64-65, 80-84; Giuseppe Ligato, "Il 'Magister' Ospedaliero Ruggero des Moulins nella crisi finale del Regno Latino di Gerusalemme: I I 82-I I 87," Antonianum 71, no. 3 (1996): 495-522.

48 Cartulaire général, I, ed. Delaville Le Roulx, no. 847.

49 Favreau-Lilie, Studien, I 46; ead., "Alle origini," 3 I-34, with papal text in Papsturkunden für Kirchen im Heiligen Lande, ed. Rudolf Hiestand (Göttingen: Vandenhoeck \& Ruprecht, 1985), 340-34I; the damaged original of this disconcerting text gives the date only as VIII $i d u s$, while the rest of the date februarii, pontificatus nostri anno quarto is found only much later in a vidimus of 1302 . 
might have been encouraged to do so by the anticipated arrival of a great German crusading army under the Emperor Frederick I, as well indeed as by their own hostility towards the Romance-speaking Hospitaller establishment.

Frederick I died in Cilicia during June I 190 but his son Frederick, Duke of Swabia, reached Acre on 7 October with some German forces, only to die there on 20 January i $191 .{ }^{50}$ At Acre, according to the late Narratio, it was not Germans from Sancta Maria in Jerusalem but northern cives who had arrived by sea from Bremen and Lübeck, probably in September I I 89, and who, in the midst of illness and starvation and at a point which would have been between the beginning of the Latin siege on 29 August I 89 and Frederick of Swabia's arrival on 7 October I 190 , set up a field hospital with a tent, reportedly made from a ship's sail, outside the town walls. ${ }^{51}$ Just who or what encouraged them to take this initiative is unknown. Possibly in mid-September and apparently by 24 December I I 90, King Guy, at the request of the Northerners' leader, who was said to be an otherwise unrecorded magister, presumably a layman, named Sibrandus and who was probably a Northern German, made a grant to the hospitalis of the Germans which his charter described as built in honour of God and Saint Mary but without any reference to Jerusalem. Guy granted the Germans the former Armenian hospice within Acre on which to build a hospital; the text stated that Sibrandus had «begun and built this hospital during the siege of Acre». ${ }^{52}$ If that was correct, this new hospital must been the field hospital outside the walls, since Acre was still under siege.

The crusaders from the West were certainly divided into distinct groups of French, English, Germans and others, but the emergence of a specifically German field hospital may have been a response not so much to a crude form of nationalism as to the same cultural and linguistic divisions which had earlier conditioned the character of Sancta Maria Alamannorum in Jerusalem. The Northern German founders, who may well have included petty nobility or men of administrative status as well as the urban cives, were not creating a religious order or a military institution but rather a charitable lay brotherhood with a single hospital which was run by a magister and was of a type familiar to them in contemporary Germany.

so Favreau-Lilie, Studien, 49.

${ }_{51}$ "De Primordiis Ordinis Theutonici Narratio," ed. Udo Arnold, in Scriptores Rerum Prussicarum, vol. 6, eds. Theodor Hirsch, Max Töppen, and Ernst Gottfried Wilhelm Strehlke (Frankfurt am Main: Salomon Hirzel, 1968), 24.

52 Hoc autem donamus et concedimus per manum magistri Sibrandi, qui hoc hospitale incepit et edificavit in obsidione Accon, see: Ernest Gottfried Wilhelm Strehlke, Tabulae Ordinis Teutonici (Berlin: Weidmann, I 869 (repr., with introduction by Hans E. Mayer, Jerusalem: Massada, 1975)), no. 25; on the date, infra, n. 73. Sibrandus was not mentioned in the Narratio. 
However, with remarkable rapidity what began as a temporary initiative became a permanent institution enjoying royal and papal approval. ${ }^{53}$

If the initial foundation was made by Northern German cives, the imperial house was soon encouraging its development. According to the Narratio, at a time which would have been at or after his arrival at Acre in October I I 90, Frederick of Swabia wrote requesting his brother Henry VI to secure papal confirmation for this German group. ${ }^{54}$ However, Henry was at Lodi in Northern Italy on 2 I January I I 9 I and at Bologna by i I February. 55 From Rome on 6 February i i 9 I Pope Clement III did issue a protection, not a confirmation, for certain Germans with their goods who were described as «the Teutonic brethren of the church of Sancta Maria in Jerusalem», but it made no mention of a hospital and it remains unclear for whom it was intended. There was no mention of Acre, which was then still in Muslim hands and within which the Germans did not at that point have a church, or of a hospital or any kind of new foundation; nor did it mention any petition from Frederick of Swabia or from Henry VI. This privilege could conceivably have been issued, without any clear understanding of the situation, in response to a message arriving directly from Acre, since three and a half months for a communication from Syria to reach the pope was a normal time, though issuing a response to a petition might take months. However, news could travel much faster than that; for example, late in November i i 87 the pope at Bologna had already heard of the fall of Jerusalem less than two months earlier on 2 October. ${ }^{56}$

Favreau maintains that the papal letter of February i I 9 I was addressed to members of the pre- I 87 ecclesia or church of Sancta Maria in Jerusalem, as it did indeed describe them, and that they were possibly in Germany where, she claims, the Sancta Maria institution or some of its members and properties had certainly survived. She also holds that many of its members had returned to Germany from Jerusalem in I I 87; they might have needed this privilege because their archive had been lost in Jerusalem. ${ }^{57}$ Since Acre did not fall until July I I 9 I, the Germans there cannot have had a church within its walls before February. Furthermore, there was

53 Cf. Militzer, Von Akkon, r o- 17.

54 “De Primordiis Ordinis Theutonici Narratio," ed. Arnold, 25-26.

ss Martin Wihoda, "The Premyslid Dynasty and the Beginnings of the Teutonic Order," in The Crusades and the Military Orders: Expanding the Frontiers of Medieval Latin Christianity, ed. Zsolt Hunyadi and Jozsef Laszlovszky (Budapest: Central European University Press, 200 I), 340-34I, 346 n. 3 I.

56 Rudolf Hiestand, "Some Reflections on the Impact of the Papacy on the Crusader States and the Military Orders in the Twelfth and Thirteenth Century," in The Crusades and the Military Orders: Expanding the Frontiers of Medieval Latin Christianity, edited by Zsolt Hunyadi and Jozsef Laszlovszky (Budapest: Central European University Press, 200 I), 6-7.

57 Favreau, Studien, 3 1, 36. 
also a puzzling mention of an Ulricus magister Teutonici hospitalis who was witness to an act at Halle in Thuringia in I 195 . Favreau considers that Ulricus represented the old Jerusalem institution, though that has been shown to be unlikely. That the ruler of a hospital in Acre would be at Halle in I 95 seems improbable and Ulricus may simply have been the governor of a local hospice at Halle. ${ }^{58}$ In June I I 9 I a newly-constructed pilgrim hospital in Brindisi, the hospitalis Alamannorum quod in Brindisino noviter est constructum which had a magister, fratres and a domus, was licensed by the local archbishop to build a church with a cemetery dedicated to Saint Mary. This new construction was presumably a response to the flow of German crusaders travelling to Syria and back from about i i 89 onwards; however, the Brindisi document of June I I 9 I contained no indication of a connection with any foundation in Jerusalem or Acre. ${ }^{99}$

The Narratio stated that after Frederick of Swabia's arrival at Acre and, evidently before his death in January I I 9 I, the cives of Bremen and Lubeck wanted to go home; at Frederick's recommendation, they transferred their hospital and all the gifts already made to it to his chaplain Konrad and his chamberlain Burchard, both of whose existence is dubious. According to the Narratio, these two renounced their secular life and dedicated the new hospital to Saint Mary, calling it the «hospital of Saint Mary of the Germans in Jerusalem» in the hope of securing the Sancta Maria church in Jerusalem; the latter point also seems unlikely. The original rulers of the German field hospital were unknown men, even though the Narratio described an imperial take-over with Frederick of Swabia acting with his nobles to replace the urban "citizens" and to impose his own officials on the brotherhood, conceivably ousting the magister Sibrandus. The Narratio stated that at that moment the Germans outside the walls of Acre, who were described as being at that time «behind the cemetery of Saint Nicholas between the hill and the river», had no possessions and did not own the place where they were established; it also made the improbable claim that there was then no other hospital for the Latin besiegers. ${ }^{60}$ In fact Ralph of Diceto described the foundation at the beginning of the siege of an English chapel with a cemetery, together with a German cemetery called the Hospitalis Alemannorum and an older cemetery known as Saint

58 Recent detailed debates in e.g. Arnold, “Jerusalem," 427-430; id., "Entstehung," 92-94; Favreau, Studien, 48, I 42-I 43; ead., "Alle origini," 37-38; Militzer, Von Akkon, I 5- I6.

59 Codice Diplomatico Brindisino, vol. I, 492-I299, eds. Annibale de Leo and Gennaro Maria Monti (Trani: Vecchi, 1940), no. 26; cf. Hubert Houben, "Templari e Teutonic nel Mezzogiorno normanno-svevo," in Il Mezzogiorno normanno-svevo, ed. Giosuè Musca (Bari: Edizioni Dedalo, 2002), 276-277; Jan-Erik Beuttel, "Studien zu den Besitzungen des Deutschen Ordens in Apulien (Forschungsbericht)," Sacra Militia 3 (2002): I 7 I-1 73.

60 "De Primordiis Ordinis Theutonici Narratio," ed. Arnold, 24-26. 
Nicholas in which by the end of the siege 124,000 men had been buried in a single year. ${ }^{61}$ Neither the location of the Germans' field hospital nor that of their earliest buildings inside Acre can be established with precision, but apparently they were respectively just outside and then inside the eastern ramparts towards their northern end near the Gate of Saint Nicholas. ${ }^{62}$ There may well have been a German cemetery outside the walls during the siege, but it would seem improbable that the Germans had a permanent church outside the walls of a city they were besieging, and it seems doubtful whether they would have completed such constructions inside the walls within some seven months of the fall of Acre to the Latins on I 2 July I I 9 I.$^{63}$

The texts drawn up close to that time and the later Narratio were evidently confused on various such points. According to the Continuation de Guillaume de Tyr which was probably written in the I 240's, the death of Frederick of Swabia in January I I 9 I took place after the conquest of Acre which actually occurred in July of that year. The Continuation said that he was buried in the maison of the Germans at Acre; if that meant in a house within the walls, it was presumably a reburial. The Continuation also said that at that time the Germans had no hospital for the sick since the Hospitallers asserted that a papal privilege gave them seignourie or jurisdiction over all hospitals in Acre so that only those subject to the Hospital could have a hospital there; that the Hospital claimed the right to choose a new master for the Germans when their master died; that the Hospital also claimed a monopoly in Acre of burials and their valuable profits, even if the death took place in the house of the Germans; and that in consequence Frederick of Swabia was, on his own instructions, buried anonymously among the poor so that the Hospitallers were unable to find his body. ${ }^{64}$ The Narratio stated that Frederick of Swabia was buried in the Teutonic church within the city, as he had requested, which would

6r Ralph of Diceto, Opera Historica, vol. 2, ed. William Stubbs (London: Her Majesty's Stationery Office, I 876), 80-8 I.

62 David Jacoby, Trade, Commodities and Shipping in the Medieval Mediterranean, vol. VI (Aldershot: Ashgate, 1 997), 206-208, 2 I 3 n. 62, figs. I -2; Pringle, "The Churches."

63 "De Primordiis Ordinis Theutonici Narratio," ed. Arnold, 26, stated that, following the recovery of Acre in July I I 9 I, the Germans erected a church, a hospital and other buildings within the walls; Jacoby, Trade, 6: 2 I 3 n. 62, considers it unlikely they could have done so by February I 192 when Guy de Lusignan granted them land on which buildings already stood: Strehlke, Tabulae, no. 27. The buildings probably existed before i 87 .

${ }^{64}$ La Continuation de Guillaume de Tyr: 1184-I197, ed. Margaret Ruth Morgan (Paris: Paul Geurhner, 1982), 99, dated in Peter W. Edbury, "Introduction," in The Conquest of Jerusalem and the Third Crusade: sources in translation, ed. Peter W. Edbury, (Aldershot: Ashgate, 1996), 7; Favreau, "Alle origini," 3 I, accepts the details in the La Continuation. 
have involved a delayed burial or a reburial. ${ }^{65}$ There was a church of Saint Nicholas outside the walls; Philip Count of Flanders, who died on I June I I 9 I, was reportedly buried in it together with more than fifty bishops, dukes and counts, ${ }^{66}$ and so was Hughes Count of Burgundy who died after the siege on 25 August I $192 .{ }^{67}$ The passage in the Continuation could have been a garbled interpretation of the old papal privilege of I 43 for Jerusalem, while in I 75 the Hospital had made a rather different agreement with the Bishop of Acre concerning wills and burials. ${ }^{68}$ Even if the Continuation were correct, it did not state that the Hospital was claiming a monopoly of certain burials on the grounds that the Germans at Acre represented their former subordinates in Jerusalem. The Hospitallers had recognized the new German hospital by 2 February 1192 when their Master, Garnier of Nablus, formally ceded some land in Acre to frater Gerardus magister hospitalis Alamannorum quod est in Accon, that is to a frater, presumably a religious, who was «master of the hospital of the Germans which is in Acre»; the charter did not mention Jerusalem. ${ }^{69}$ No text of I I 91 or I 192 mentioned a census owed to the papacy. ${ }^{70}$

The course of these events has been confused by various forgeries $;^{71}$ these include two false papal privileges of I 6 July I I $88 /$ I 190 and I 2 February I $192 . .^{72}$ Three genuine charters, that of King Guy of $\mathrm{I}$ I 90 and those of Guy and of the Hospitallers both of February i I 92, explicitly recognized the existence of the Teutonic hospital but not one of the three referred to Jerusalem. ${ }^{73}$ Apparently the notion

${ }_{65}$ "De Primordiis Ordinis Theutonici Narratio," ed. Arnold, 26.

66 Sigebertus, "Continuatio Aquicinctina," in Monumenta Germaniae Historica: Scriptores, vol. 6, ed. Ludwig Bethmann (Hannover: Impensis Bibliopolii Aulici Hahniani, I 844), 427.

${ }_{67}$ Favreau-Lilie, Studien, 37.

68 Cartulaire général, I, ed. Delaville Le Roulx, no. 47 I; cf. Riley-Smith, The Knights, 405-406.

69 Strehlke, Tabulae, nos. 26-27, which mention Gerardus, magister on 2 February 1192 and Curaudus hospitalis Alammanorum preceptor on 10 February i 192, one or the other, or both, conceivably as errors for Konrad the supposed founder in I I 90: Arnold, "Entstehung," 86-87; Militzer, Von Akkon, 2 I.

$7^{\circ}$ Le Liber Censuum de l'Eglise Romaine, vol. I, eds. Paul Fabre and Louis Duchesne (Paris: Fontemoing, 1910), 238, recorded two morabottini owed to the pope by the Hospitale novum S. Marie at Acre; the editors claim that the "new" hospital was undoubtedly that of the Hospitallers, while Favreau, "Alle origini," 32, considers it was the German hospital and that it was already making the payment in I 192. However, arguments based on this census fail because, though the Liber originated in I 192, the reference to a Hospitale novum was a later addition: Le Liber Censuum, I, ed. Fabre and Duchesne, 57, 8 I.

${ }_{71}$ Mayer, in Strehlke, Tabulae, 25 n. I 2.

72 Papsturkunden für Templer, ed. Hiestand, 306-309; Papsturkunden für Kirchen, ed. Hiestand, 343-344.

73 Strehlke, Tabulae, nos. 25-27. Hans Eberhard Mayer, Die Kanzlei der lateinischen Könige von Jerusalem, vol. 2 (Hannover: Hahn, 1996), 404, 429-432, 88 I, notes that in no. 25, hitherto 
of a Jerusalem "continuity" for the Germans was a slightly later invention. There was no known juridical or institutional link, no known continuity of personnel, no sign of knightly membership or of military activity, no indication of any transfer of an archive and no survival of any pre- i 87 documents in the archive of the Teutonic Order, though there may have been documents at Sancta Maria in Jerusalem which were lost in I I 87. The Northern German crusaders could have included a group of carers who, spontaneously perhaps, founded a field-hospital. Yet the existence as recently as I I 87 of the German hospice in Jerusalem can scarcely have been out of mind for those at Acre two years later in I 189 or I 190 ; nor would the long-standing particularism which resulted in German hostility to the Hospital have evaporated.

In 229 Frederick II gave to the Teutonic Order - damus et concedimus - the domus in Jerusalem which, he claimed, "Germans," described as olim Theutoni$c i$, had held there before i i 87; technically that was not a confirmation. ${ }^{74}$ Favreau holds that after I 87 the Hospitallers in Germany sought to acquire the German possessions of Sancta Maria Alamannorum, possessions which she considers did exist, and that the papal privilege of 6 February I I9 I was issued in response to resistance on the part of a Sancta Maria institution which, she argues, survived for some years as a Restkorporation until the Teutonic Order took its purported but unidentified German possessions. Favreau maintains that in I 229 Frederick II confirmed the Teutonic Order as proprietor of an entire patrimony which German crusaders and pilgrims had granted to Sancta Maria, that «in all probability » it included «certain lands» in Germany.75 Yet there is no real evidence, apart from the papal privileges of I I 43, that there were any such lands in Germany; nor is there any sign that after i i 87 either the Hospital, or later the Teutonic Order, held German possessions which had belonged to Sancta Maria before i I $87 .{ }^{6} \mathrm{Had}$ the Germans at Acre claimed such properties as early as I I90 or I I9I in the hope of acquiring the prestige of a Jerusalem origin, they would have provoked a major dispute with the Hospital, as did in fact occur some thirty years later in I 229. It was rather the Hospitallers who, according at least to the Continuation de Guillaume

dated is September I 190 , the words medio septembris are an interpolation; technically the document could date between 25 December 1 i 98 and 24 December I 190, but mid-September seems approximately correct.

74 Jean Louis Alphonse Huillard-Bréholles, Historia diplomatica Friderici Secundi, vol. 3 (Paris: Plon, I 852), I 26-1 27. Apparently, the Sancta Maria hospital was not heard of after I 229: Dan Bahat, "Hospices and Hospitals in Mamluk Jerusalem," in Towns and Material Culture in the Medieval Middle East, ed. Yaacov Lev (Leiden: Brill, 2002), 73-88.

75 Favreau, "Alle origini," 34, 39-43.

76 Cf. Militzer, Von Akkon, 16. 
de Tyr, claimed rights over the Germans; reportedly they cited a papal privilege, perhaps that of I I 43 which the Hospital did preserve, but it would not necessarily follow that the Germans at Acre came from Sancta Maria in Jerusalem. Many chroniclers did not make the claim for continuity.7 The Narratio was an obvious but late exception and Jacques de Vitry, the well-informed Bishop of Acre, was to say, but very vaguely and only years later, that the Teutonic Order had originated in Jerusalem. ${ }^{78}$ After I I 9 I there were numerous documents which claimed some sort of continuity; for example, Frederick II's repeated references to otherwise unknown grants supposedly made to Sancta Maria by Frederick I, by Frederick of Swabia and by other unnamed predecessors. ${ }^{79}$ In strict logic such references prove little.

A number of military orders invented legendary origins in Jerusalem ${ }^{80}$ and the Germans' efforts to create a continuity with Sancta Maria Alamannorum may have begun as part of a search for prestige rather than for property. In I 196 the new German institution was recognized by the pope as composed of regular fratres; it was entitled hospitalis Sancta Maria Alamannorum Ierosolimitanum, implying a hospital with a Jerusalem connection, and it was confirmed in possession of a number of properties in Syria but none elsewhere. ${ }^{81}$ The German hospital formally became a military-religious order only in I 198 when, in the Templars' house at Acre, the Master of the Temple handed over a copy of the Templar rule and knighted the first Teutonic miles. ${ }^{82}$ The Hospital could scarcely have made such gestures. It seems that, in the midst of their many difficulties and at a moment when their order's affairs were in confusion and without firm leadership, the Hospitallers mismanaged their relations with a group of Germans who might have been absorbed within the Hospital, which thus lost control of a considerable element of potential support and resources which went to the new order. Whether or not the Hospitallers were providing hospital services to the Latins besieging Acre, certain Germans took the initiative in creating a German field-hospital and that provided an opportunity for a German escape from Hospitaller control.

77 Some examples in Helen Nicholson, Templars, Hospitallers and Teutonic Knights: Images of the Military Orders II28-I29I (Leicester: Leicester University Press, I995), I 42 n. I7, I68 n. 80.

${ }_{78}$ Vitry, "Historia," I084-1085.

79 Favreau-Lilie, Studien, 100-1 6 I et passim; ead., "Alle origini," 39-43.

8० E.g. Nicholson, Templars, I I 2-1 I6; Anthony Luttrell, "Préface," in Antoine Calvet, Les Légendes de l'Hôpital de Saint-Jean de Jérusalem (Paris: Presses de l'Université de Paris Sorbonne, 2000), 8-I I and 2 I-4I.

81 Strehlke, Tabulae, no. 296.

82 "De Primordiis Ordinis Theutonici Narratio," ed. Arnold, 26-29. 


\section{PRIMARY SOURCES:}

“Annales Egmundani." In Monumenta Germaniae Historica: Scriptores. Vol. I 6, edited by Georg H. Pertz, 442-479. Hannover: Impensis Bibliopolii Aulici Hahniani, i 859.

Arnold of Lübeck. "Chronica Slavorum.” In Monumenta Germaniae Historica: Scriptores. Vol. 2 I, edited by Georg Heinrich Pertz, I I -250. Hannover: Impensis Bibliopolii Aulici Hahniani, I 869.

Cartulaire général de l'Ordre des Hospitaliers de S. Jean de Jérusalem (IIOO-I3IO). Vol. I. (IIO0-I200). Edited by Joseph Delaville Le Roulx. Paris: Ernest Leroux, I 894.

Codice Diplomatico Brindisino. Vol. I. 492-1299. Edited by Annibale de Leo and Gennaro Maria Monti. Trani: Vecchi, I 940.

“De Primordiis Ordinis Theutonici Narratio." Edited by Udo Arnold. In Scriptores Rerum Prussicarum. Vol. 6, edited by Theodor Hirsch, Max Töppen, and Ernst Gottfried Wilhelm Strehlke, 22-29. Frankfurt am Main: Salomon Hirzel, 1968.

Ipra, Johannes Longus de. "Chronica Monasterii Sancti Bertini." Edited by Oswald Holder-Egger. In Monumenta Germaniae Historica: Scriptores. Vol. 25, edited by Georg Heinrich Pertz, 736-866. Hannover: Impensis Bibliopolii Aulici Hahniani, I 88o.

La Continuation de Guillaume de Tyr: 1184-II97. Edited by Margaret Ruth Morgan. Paris: Paul Geurhner, I 982.

Le Cartulaire du Chapitre du Saint-Sépulchre de Jérusalem. Edited by Geneviève Bresc-Bautier. Paris: Paul Geuthner, 1984.

Le Liber Censuum de l'Eglise Romaine. Vol. I. Edited by Paul Fabre and Louis Duchesne. Paris: Fontemoing, I 9 I 0.

Oorkondenboek van het Sticht Utrecht tot I30r. Vol. I. Edited by Samuel Muller, Arie Cornelis Bouman, Klaas Heeringa, and Frans Ketner. Utrecht: Oosthoek, 1920.

Otto Frisingensis. “Gesta Friderici I. Imperatoris.” In Scriptores Rerum Germanicarum in usum Scholarum, edited by Georg Waitz, I-16I. Hannover: Impensis Bibliopolii Hahniani, I 9 I 2.

Papsturkunden für Kirchen im Heiligen Lande. Edited by Rudolf Hiestand. Göttingen: Vandenhoeck \& Ruprecht, I 985.

Papsturkunden für Templer und Johanniter: Neue Folge. Edited by Rudolf Hiestand. Göttingen: Vandenhoeck \& Ruprecht, 1984.

Peregrinationes Tres: Saewulf, John of Wiirzburg, Theodoricus. Edited by Robert B. C. Huygens. Turnhout: Brepols, I 994.

Ralph of Diceto. Opera Historica. Vol. 2. Edited by William Stubbs. London: Her Majesty's Stationery Office, i 876.

Sancti Bernardi Opera. Vol. 8. Edited by Jean Leclercq and Henri Rochais. Rome: Editiones Cistercienses, 1977.

Sigebertus. "Continuatio Aquicinctina." In Monumenta Germaniae Historica: Scriptores. Vol. 6, edited by Ludwig Bethmann, 406-438. Hannover: Impensis Bibliopolii Aulici Hahniani, I 844.

Strehlke, Ernest Gottfried Wilhelm. Tabulae Ordinis Teutonici. Berlin: Weidmann, I 869 (repr., with introduction by Hans E. Mayer, Jerusalem: Massada, I 975). 
Tönnies, Bernhard. Die Handschriften der Thüringer Universitäts- und Landesbibliothek Jena. Vol I. Die mittelalterlichen lateinischen Handschriften der Electoralis-Gruppe. Wiesbaden: Otto Harrassowitz, 2002.

Urkundenbuch der Stadt Duisburg. Vol. r. Edited by Joseph Milz [et al.]. Duisburg: Droste, 1989.

Vitry de, Jacques. "Historia Orientalis." In Gesta Dei per Francos. Vol. 2. Edited by Jacques Bongars. Hannover: Typis Wechelianis, apud heredes I. Aubrii, I 6 I I.

\section{SECONDARY SOURCES:}

Arnold, Udo. "Entstehung und Frühzeit des Deutschen Ordens." In Die geistlichen Ritterorden Europas, edited by Josef Fleckenstein and Manfred Hellmann, 81-i 07. Sigmaringen: Thorbecke, 1980.

Arnold, Udo. "Jerusalem und Akkon: zur Frage von Kontinuitat oder Neugriindung des Deutschen Ordens I I $90 . "$ Mitteilungen des Institutes für Österreichische Geschichtsforschung 86 (1978): 418-432.

Bahat, Dan. "Hospices and Hospitals in Mamluk Jerusalem." In Towns and Material Culture in the Medieval Middle East, edited by Yaacov Lev, 73-88. Leiden: Brill, 2002.

Barber, Malcolm. "The Career of Philip of Nablus in the Kingdom of Jerusalem." In The Experience of Crusading. Vol. 2, Defining the Crusader Kingdom, edited by Peter Edbury and Jonathan Phillips, 60-75. Cambridge: Cambridge University Press, 2003.

Beltjens, Alain. "Comment l'Hôpital de Jérusalem, une Institution religieuse et hospitalière d'Origine bourgeoise, a-t-il pu se transformer en un Ordre militaire et accessoirement hospitalier?" Studi Melitensi Io (2002): 7-60.

Beuttel, Jan-Erik. "Studien zu den Besitzungen des Deutschen Ordens in Apulien (Forschungsbericht)." Sacra Militia 3 (2002): I 6 I-2 2 2.

Bieberstein, Klaus, and Sabine Bieberstein. "St. Thomas Alemannorum oder St. Peter ad Vincula? Zur historischen Identifizierung einen wiederentdeckten Kreuzfahrerkirche in der Altstadt Jerusalems." Zeitschrift des Deutschen Palästina-Vereins I04 (1988): I $52-16$ I.

Borchardt, Karl. "Military Orders in East Central Europe." In Autour de la première Croisade, edited by Michel Balard, 257-254. Paris: Publications de la Sorbonne, 1996.

Borchardt, Karl. "Spendenaufrufe der Johanniter aus dem I 3 . Jahrhundert." Zeitschrift für bayerische Landesgeschichte 56 (1993): I- 6 I.

Borchardt, Karl. "The Templars in Central Europe." In The Crusades and the Military Orders: Expanding the Frontiers of Medieval Latin Christianity, edited by Zsolt Hunyadi and Jozsef Laszlovszky, 233-244. Budapest: Central European University Press, $200 \mathrm{I}$.

Borchardt, Karl. "Two Forged Thirteenth-Century Alms-Raising Letters used by the Hospitallers in Franconia." In The Military Orders. Vol. I, Fighting for the Faith and Caring for the Sick, edited by Malcolm Barber and Helen Nicholson, 52-56. Aldershot: Ashgate, 1994.

Bronstein, Judith. The Hospitallers in the Holy Land: Financing the Latin East, II87-I274. Woodbridge: Boydell Press, 2005. 
Bulst-Thiele, Marie Luise. Sacrae Domus Militiae Templi Hierosolymitani Magistri: Untersuchungen zur Geschichte des Templerordens II I8/9-1314. Göttingen: Vandenhoeck \& Ruprecht, I 974.

Delaville le Roulx, Joseph. Les Hospitaliers en Terre Sainte et à Chypre: IIoo-I3Io. Paris: Ernest Leroux, I 904.

Demurger, Alain. Chevaliers du Christ: les Ordres religieux-militaires au Moyen Age (XI- XVI siecle). Paris: Seuil, 2002.

Der Johanniter-Orden / der Malteser-Orden: der ritterliche Orden des hl. Johannes vom Spital zu Jerusalem - seine Aufgaben, seine Geschichte. Edited by Adam Wienand. Cologne: Wienand, I 988, 3 rd edition.

Edbury, Peter W. "Introduction." In The Conquest of Jerusalem and the Third Crusade: sources in translation, edited by Peter W. Edbury, 4-I 4. Aldershot: Ashgate, I 996.

Favreau-Lilie, Marie-Luise. "Alle origini dell'Ordine Teutonico: continuità o nuova fondazione dell'Ospedale Gerosolimitano degli Alemanni?” In Militia Sacra: gli Ordini militari tra Europa e Terrasanta, edited by Enzo Coli et al., 29-47. Perugia: San Bevignate, I994.

Favreau, Marie-Luise. Studien zur Frühgeschichte des Deutschen Ordens. Stuttgart: Ernst Klett, 1974.

Favreau, Marie-Louise. "Zur Pilgerfahrt des Grafen Rudolf von Pfullendorf: ein unbeachteter Originalbrief aus den Jahr i I 80." Zeitschrift für die Geschichte des Oberrheins 123 , no. 84 (1975): 3 I-46.

Folda, Jaroslav. The Art of the Crusaders in the Holy Land: 1098-1187. Cambridge: Cambridge University Press, I 995.

Forey, Alan. The Military Orders from the Twelfth to the Early Fourteenth Centuries. Basingstoke: Macmillan, 1992.

Hiestand, Rudolf. “Die Anfänge der Johanniter." In Die geistlichen Ritterorden Europas, edited by Josef Fleckenstein and Manfred Hellmann, 3 I-80. Sigmaringen: Thorbecke, 1980.

Hiestand, Rudolf. "Kingship and Crusade in Twelfth-Century Germany." In England and Germany in the High Middle Ages, edited by Alfred Haverkamp and Hanna Vollrath, 235-266. London: Oxford University Press, 1996.

Hiestand, Rudolf. "Some Reflections on the Impact of the Papacy on the Crusader States and the Military Orders in the Twelfth and Thirteenth Century." In The Crusades and the Military Orders: Expanding the Frontiers of Medieval Latin Christianity, edited by Zsolt Hunyadi and Jozsef Laszlovszky, 3-20. Budapest: Central European University Press, $200 \mathrm{I}$.

Houben, Hubert. “Templari e Teutonic nel Mezzogiorno normanno-svevo.” In Il Mezzogiorno normanno-svevo e le Crociate, edited by Giosuè Musca, 25 I-288. Bari: Edizioni Dedalo, 2002.

Huillard-Bréholles, Jean Louis Alphonse. Historia diplomatica Friderici Secundi. Vol. 3. Paris: Plon, I 852. 
Jacoby, David. Trade, Commodities and Shipping in the Medieval Mediterranean. Vol. 6. Aldershot: Ashgate, 1997.

Jux, Anton. Der Johanniterkommende Herrenstrunden nebst Pfarrgeschichte. Bergisch Gladbach: Kulturamt Bergisch-Gladbach, 1956.

Kluger, Helmuth. Hochmeister Hermann von Salza und Kaiser Friedrich II.: Ein Beitrag zur Frühgeschichte des Deutschen Ordens. Marburg: N. G. Elwert, 1987.

Leclercq, Jean. "L'Encyclique de Saint Bernard en faveur de la Croisade." Revue Bénédictine 7I (I97I): 290-29I.

Ligato, Giuseppe. "Il 'Magister' Ospedaliero Ruggero des Moulins nella crisi finale del Regno Latino di Gerusalemme: I I 82- I I 87." Antonianum 71, no. 3 (1996): 495-522. Loud, Graham. "Some Reflections on the Failure of the Second Crusade." Crusades 4 (2005): I-4.

Luttrell, Anthony. "Ermengol de Aspa Provisor of the Hospital: I i 88." Crusades 4 (2005): I 5-I9.

Luttrell, Anthony. "Gli Ospedalieri nel Mezzogiorno." In Il Mezzogiorno normanno-svevo e le Crociate, edited by Giosuè Musca, 65-94. Bari: Edizioni Dedalo, 2002.

Luttrell, Anthony. "Los Orígines de la Encomienda templaria" [forthcoming].

Luttrell, Anthony. "Préface." In Les Légendes de l'Hôpital de Saint-Jean de Jérusalem, edited by Antoine Calvet, 8-i I. Paris: Presses de l'Université de Paris Sorbonne, 2000.

Luttrell, Anthony. "Templari e Ospitalieri: alcuni confronti." In I Templari la guerra e la santità, edited by Simonetta Cerrini, Fulvio Bramato, and Franco Cardini, I 33 - I 52. Rimini: Iniziative Editoriali Il Cerchio, 2000.

Luttrell, Anthony. "The Earliest Hospitallers." In Montjoie: Studies in Crusade History in Honour of Hans Eberhard Mayer, edited by Benjamin Kedar et al., 37-54. Aldershot: Variorum, 1997.

Luttrell, Anthony. "The Earliest Templars." In Autour de la première Croisade, edited by Michel Balard, 193-202. Paris: Publications de la Sorbonne, 1996.

Luttrell, Anthony T. "The Hospitalier Background of the Teutonic Order." In Religiones Militares: contributi alla storia degli ordini religioso-militari nel Medioevo, edited by Anthony T. Luttrell and Francesco Tommasi, 27-42. Biblioteca di militia sacra 2. Città di Castello: Selecta, 2008.

Luttrell, Anthony. "The Hospitallers in Twelfth-Century Constantinople." In The Experience of Crusading. Vol. I, Western Approaches, edited by Marcus Graham Bull and Norman Housley, 225-232. Cambridge: Cambridge University Press, 2003.

Mayer, Hans Eberhard. Die Kanzlei der lateinischen Könige von Jerusalem. Vol. 2. Hannover: Hahn, 1996.

Militzer, Klaus. Von Akkon zu Marienburg: Verfassung, Verwaltung und Socialstruktur des Deutschen Ordens 1190-1310. Marburg: N. G. Elwert, 1999.

Nicholson, Helen. Templars, Hospitallers and Teutonic Knights: Images of the Military Orders II28-I29I. Leicester: Leicester University Press, I 995. 
Phillips, Jonathan. "Papacy, Empire and the Second Crusade." In The Second Crusade: Scope and Consequences, edited by Jonathan Phillips and Martin Hoch, I 5-32. Manchester: Manchester University Press, $200 \mathrm{I}$.

Pringle, Denys. "The Churches of the Crusader Kingdom of Jerusalem." Vol. 3. Cambridge [forthcoming].

Riley-Smith, Jonathan. "Guy of Lusignan, the Hospitallers and the Gates of Acre." In Dei Gesta per Francos: Crusade Studies in Honour of Jean Richard, edited by Michel Balard [et al.], i I I- I I s. Aldershot: Routledge, 200 I.

Riley-Smith, Jonathan. The Knights of St. John in Jerusalem and Cyprus: c. Ioso-I3Io. London: MacMillan, I 967.

Riley-Smith, Jonathan. "The Origins of the Commandery in the Temple and the Hospital." In La Commanderie: Institution des Ordres Militaires dans l'Occident Médiéval, edited by Anthony Luttrell and León Pressouyre, 9- I 8. Paris: Comité des travaux historiques et scientifiques, 2002.

Rödel, Walter Gerd. Das Grosspriorat Deutschland des Johanniter-Ordens im Übergang vom Mittelalter zur Reformation anhand der Generalvisitationsberichte von 1494/95 und I 540/4I. Cologne: Wienand, I 972, 2nd edition.

Tyerman, Christopher. The Invention of the Crusades. Basingstoke: Red Globe Press, 1998.

Weltin, Maximilian. "Die Anfänge der Johanniterkommenden Mailberg und Stroheim." Mitteilungen des Oberösterreichischen Landesarchivs I 8 (1996): I 87-203.

Wihoda, Martin. "The Premyslid Dynasty and the Beginnings of the Teutonic Order." In The Crusades and the Military Orders: Expanding the Frontiers of Medieval Latin Christianity, edited by Zsolt Hunyadi and Jozsef Laszlovszky, 337-347. Budapest: Central European University Press, 200 I.

Winter van, Johanna Maria. "Les Seigneurs de Sainte-Catherine à Utrecht les premiers Hospitaliers au nord des Alpes." In Autour de la première Croisade, edited by Michel Balard, 239-246. Paris: Publications de la Sorbonne 1996.

Winter van, Johanna Maria. Sources concerning the Hospitallers of St. John in the Netherlands: 14 th-I 8 th Centuries. Leiden: Brill, 1998. 